\title{
Pathologic Fracture Due to an Osteoblastoma of the Humerus Shaft: A Case Report
}

\author{
Jae-Kwang Yum, M.D., Ph.D., Jae-Gu Park, M.D., and Min Kyu Kim, M.D. \\ Department of Orthopaedic Surgery, Sanggye Paik Hospital, Inje University College of Medicine, Seoul, Korea
}

Osteoblastoma is rare, benign, bone-forming tumor that often occur in the spine. There are few reports of osteoblastomas resulting in pathologic fractures involving long bones. Authos report a unique case of a pathologic fracture due to an osteoblastoma of the humerus shaft. The tumor was treated successfully by curettage, intramedullary nailing and bone allograft.

Key words: humerus shaft, pathologic fracture, osteoblastoma

Osteoblastoma is uncommon, primary bone tumor that actively produce osteoid and primitive woven bone. This tumor is most frequently observed in patients younger than 30 years, although the age distribution ranges from 2 to 75 years. ${ }^{1,2)}$ The bony trabeculae are variably calcified; some have much calcification, while others have abundant thick, pink osteoid with no mineralisation making the lesion friable. They may affect any bone; the spine and sacrum are common sites ${ }^{3)}$ and the humerus is a very rare site.

Authors experienced an unusual pathological fracture due to an osteoblastoma located at the humerus shaft and this report describes the clinical, pathological and radiological findings and treatment with an intramedullary nail and bone allograft after curettage of the lesion of pathologic fracture due to an osteoblastoma.

\section{Case Report}

An 18-year-old male, who had mental retardation due to cerebral palsy and intermittent epilepsy, fractured his left arm after slipping. There was tenderness over the midshaft of the humerus. His serum alkaline phosphatase level was slightly elevated (202 IU/L). A radiograph of the left humerus showed intramedullary trabeculation at mid-shaft with a transverse fracture (Fig. 1). Magnetic resonance

Received September 9, 2011 Revised November 17, 2011 Accepted November 25, 2011 Correspondence to: Jae-Kwang Yum, M.D., Ph.D.

Department of Orthopaedic Surgery, Sanggye Paik Hospital, Inje University College of Medicine, Sanggye 7-dong, Nowon-gu, Seoul 139-707, Korea

TEL: +82-2-950-1032 FAX: +82-2-934-6342 E-mail: yumccf@hanmail.net imaging (MRI) showed a focal sclerotic lesion involving both the medullary and cortical portions around the fracture site and a small enhancing portion at the periphery (Fig. 2).

The tumor was biopsied. Intra-operative findings revealed that the bone forming tumor had a cortical component with fibrotic septae filling the canal and the distal fracture fragment margin showed cortical osteolysis. No soft tissue mass was observed. The histological examination showed osteoid islands composed of osteoblasts and
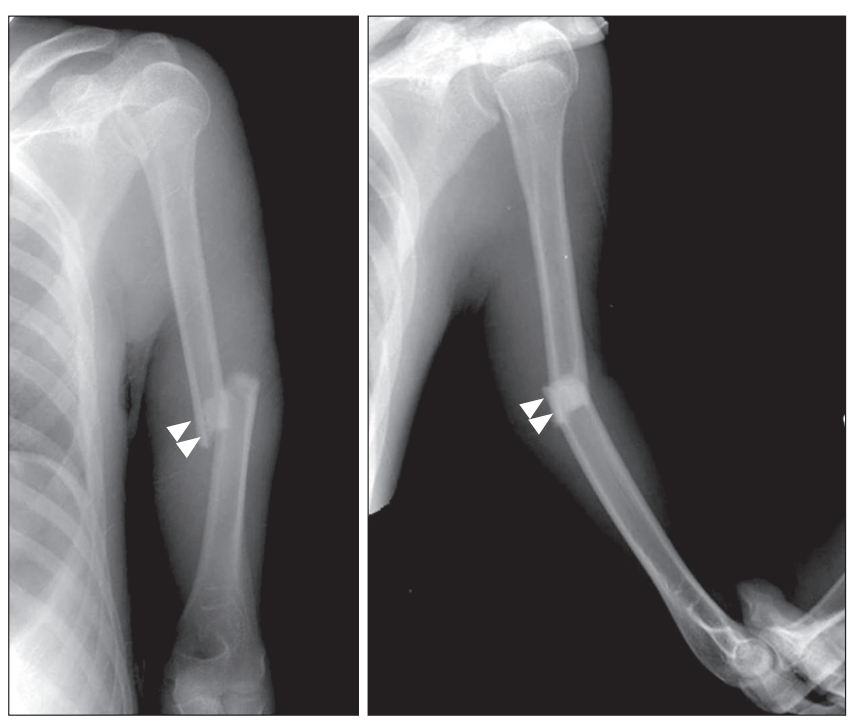

Figure 1. Initial radiographs show a transverse humerus shaft fracture with displacement. At the fracture site, a radiopaque lesion is identified in the medullary space of the proximal fragment of the humerus (white arrows). 
Jae-Kwang Yum, et al,

ossification with mineralization (Fig. 3).

Surgical exploration was performed 2 weeks after the trauma. A 7-cm linear skin incision was made at the anterolateral aspect of the upper arm and after the brachialis muscle was split, the fracture site was exposed. We found a greyish-brown mass filling the medullary cavity at the fracture site and the tumor mass was excised extended intralesionally using an osteotome, curette and rongeur. Adequate resection of the tumor was confirmed by intraoperative fluoroscopy.
After excision of the lesion, authors inserted an intramedullary nail with proximal and distal interlocking. Bone graft with an allograft was done at the fracture site. At the 6-month follow-up after the operation, radiographs showed complete radiological bone union at the mid-shaft of the humerus (Fig. 4).
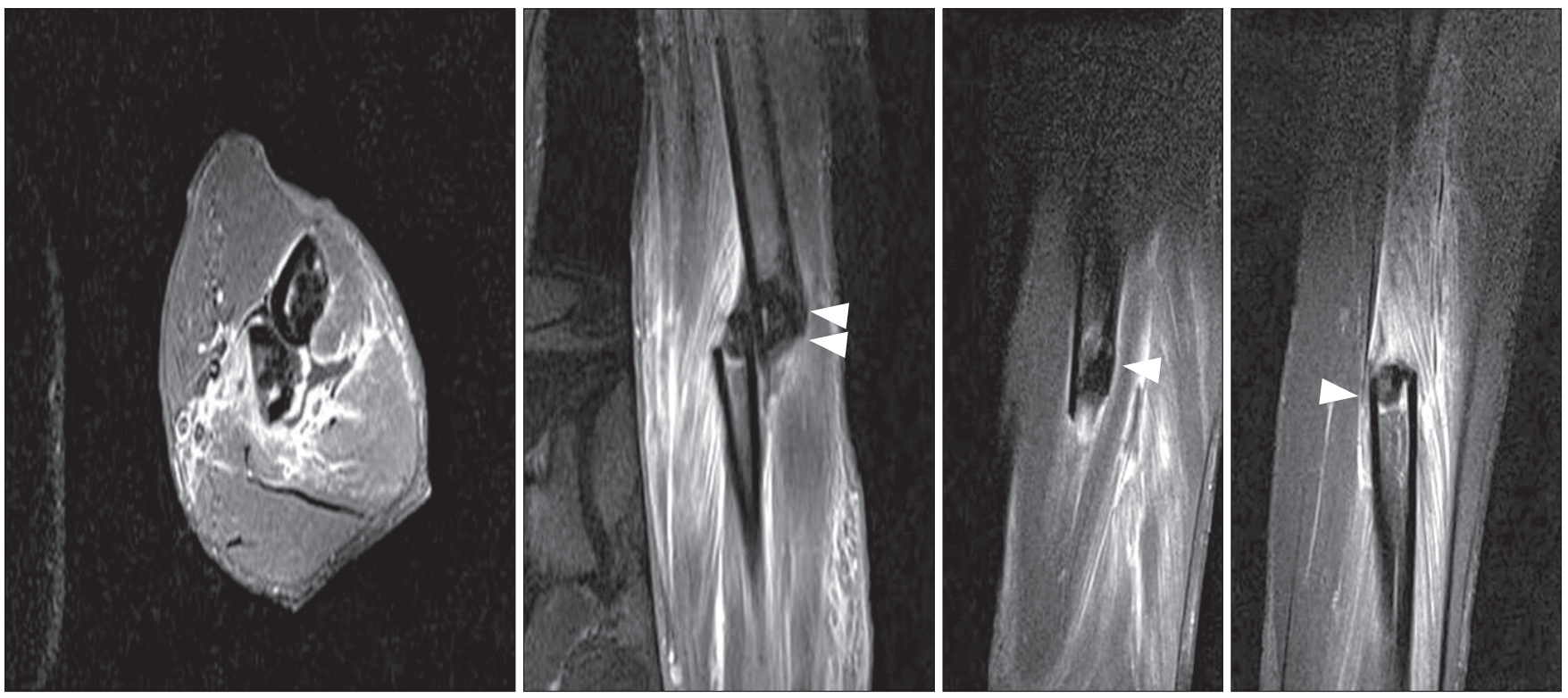

Figure 2. Enhanced MRI shows a focal sclerotic lesion involving both the medullary and cortical portions around the fracture site and a small enhancing portion at the periphery, suggesting a bone-forming tumor (white arrows).

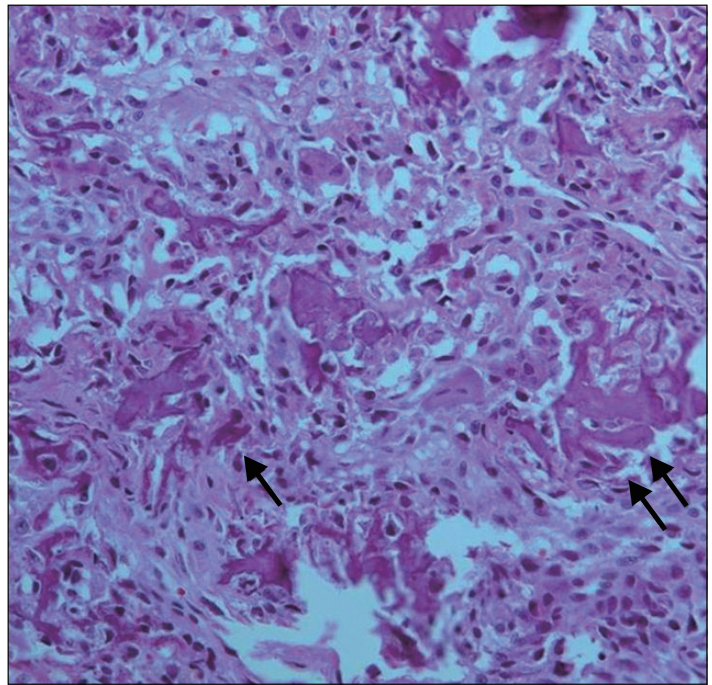

Figure 3. Photomicrograph of the curettage specimen shows osteoid islands composed of osteoblasts and ossification with mineralisation (black arrows; haematoxylin \& eosin, ×400).
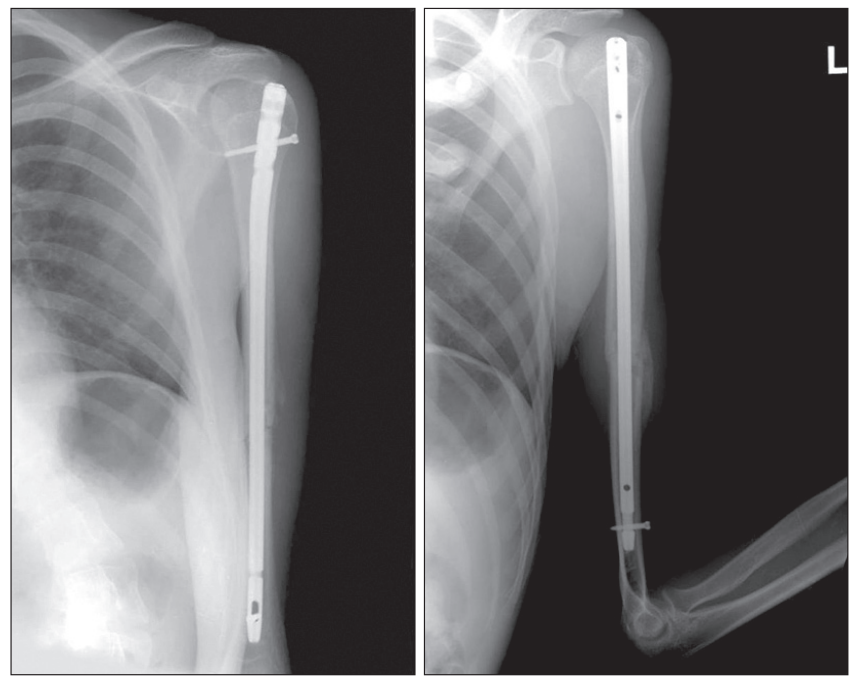

Figure 4. Radiographs 6 months after the operation show radiological bone union. 
Pathologic Fracture Due to an Osteoblastoma of the Humerus Shaft: A Case Report

\section{Discussion}

An osteoblastoma is a rare, solitary, bone-producing tumor most commonly located in the vertebral column or metaphysis of a long bone. Its histopathology is similar to that of the nidus of an osteoid osteoma, but it is larger. Thus, it is also known as a giant osteoid osteoma. Men are affected more frequently than women ( $2: 1$ ratio) and the osteoblastoma is observed most frequently in patients under 30 years of age. ${ }^{1-3)}$

A common clinical manifestation of osteoblastoma is mild local pain. The characteristic clinical features of osteoid osteoma including severe pain, worse at night and relieved by aspirin, do not occur in osteoblastoma. ${ }^{4,5)}$ Osteoblastoma occurs most often within the posterior elements of the vertebral column but also affect the long tubular bones in approximately one-third of cases; the proximal femur, distal femur and proximal tibia are the most frequent sites of involvement. The humerus is a very rare site. In the long tubular bones, the osteoblastoma is located in the metaphysis in $75 \%$ of cases and in the diaphysis in the remaining cases with very few lesions reported in epiphyseal locations.

Radiographs are the most helpful imaging technique for diagnosing osteoblastoma. Within the long bones, an osteoblastoma appears as a round or oval well-circumscribed osteolytic lesion with a thin shell of peripheral new bone. The lesion may or may not have calcification of varying degrees. The lesion has large areas of bone destruction and variable sclerosis. Approximately two-thirds of osteoblastomas in tubular bones are located within the cortex and the other one-third in the medullary canal. An osteoblastoma may result in cortical destruction or extra-osseous soft tissue expansion. ${ }^{6,7)}$ Computed tomography $(\mathrm{CT})$ provides information about the size and extent of the lesion in the cortical bone, and aids the preoperative evaluation and planning for surgery. MRI is also helpful for depicting the extent of the lesion within the medulla and any soft tissue involvement. Bone scintigraphy is sensitive but not specific and it shows intense focal activity at the tumor site.

Osteoblastomas should be treated surgically when detected, because the tumor may be clinically aggressive despite its benign nature. For lesions involving expendable bones, such as ribs or the fibula, resection with wide margins is preferred. In most other locations, extended intralesional curettage is sufficient. Reconstruction may be required for a sizable defect. Close follow-up is necessary for the early detection of recurrence as well as appropriate rehabilitation and recovery.,

The prognosis of this tumor is very good, regardless of the type of excision. After complete removal of the tumor, recurrences are rare even though the relapse or, more rarely, malignant change is possible. So postoperative follow-up is necessary to ensure an optimal outcome.

In conclusion, pathologic fracture of the humerus shaft due to osteoblastoma is very rare. An osteoblastoma is difficult to diagnose early because its clinical manifestations are minimal. When a younger person has pain involving a long bone, especially the metaphysis, without trauma, it should be evaluated further. It is important to recognise this tumor.

\section{References}

1. Papagelopoulos PJ, Galanis EC, Sim FH, Unni KK. Clinicopathologic features, diagnosis, and treatment of osteoblastoma. Orthopedics. 1999;22:244-7.

2. Frassica FJ, Waltrip RL, Sponseller PD, Ma LD, McCarthy EF Jr. Clinicopathologic features and treatment of osteoid osteoma and osteoblastoma in children and adolescents. Orthop Clin North Am. 1996;27:559-74.

3. Greenspan A. Benign bone-forming lesions: osteoma, osteoid osteoma, and osteoblastoma. Clinical, imaging, pathologic, and differential considerations. Skeletal Radiol. 1993;22:485500 .

4. Marsh BW, Bonfiglio M, Brady LP, Enneking WF. Benign osteoblastoma: range of manifestations. J Bone Joint Surg Am. 1975;57:1-9.

5. Kirwan EO, Hutton PA, Pozo JL, Ransford AO. Osteoid osteoma and benign osteoblastoma of the spine. Clinical presentation and treatment. J Bone Joint Surg [Br]. 1984;66:21-6.

6. Lichtenstein L. Benign osteoblastoma; a category of osteoidand bone-forming tumors other than classical osteoid osteoma, which may be mistaken for giant-cell tumor or osteogenic sarcoma. Cancer. 1956;9:1044-52.

7. Kroon HM, Schurmans J. Osteoblastoma: clinical and radiologic findings in 98 new cases. Radiology. 1990;175:783-90.

8. Golant A, Lou JE, Erol B, Gaynor JW, Low DW, Dormans JP. Pediatric osteoblastoma of the sternum: a new surgical technique for reconstruction after removal: case report and review of the literature. J Pediatr Orthop. 2004;24:319-22.

9. Saglik Y, Atalar H, Yildiz Y, Basarir K, Gunay C. Surgical treatment of osteoblastoma: a report of 20 cases. Acta Orthop Belg. 2007;73:747-53. 
Jae-Kwang Yum, et al,

\section{골모세포종으로 인한 상완골 간부의 병적 골절: 증례 보고 \\ 염재광 - 박재구 • 김민규 \\ 인제대학교 상계백병원 정형외과}

골모세포종은 뼈를 생성하는 드문 양성 종양으로 척추에 주로 발생하지만 장골에서 병적 골절을 발생시키는 골모세포종에 대한 보고 는 거의 없다. 저자들은 상완골 간부에 골모세포종으로 인한 병적 골절에 대하여 종양은 소파술을 시행하였고 병적 골절에 대해서는 골 수강내 금속정을 이용한 고정술을 시행하여 안정적인 골유합을 얻을 수 있었다. 저자들은 이처럼 보기 드문 상완골 간부애 골모세포종 으로 인한 병적 골절을 진단하고 치료하는 경험을 하였기에 이에 관한 증례를 보고하고자 한다.

색인단어: 상완골 간부, 병적 골절, 골모세포종

접수일 2011년 9월 9일 심사수정일 2011년 11월 17일 게재확정일 2011년 11월 25일

교신저자 염재광

서울시 노원구 상계 7동, 상계백병원 정형외과

TEL 02-950-1032, FAX 02-934-6342, E-mail yumccf@hanmail.net 